PNL-6583

UC-606

if

\title{
DOE Radiological Calibrations Intercomparison Program: Results of Fiscal Year 1987
}

\author{
F. M. Cummings \\ J. C. McDonald
}

June 1988

Prepared for

the U.S. Department of Energy

Assistant Secretary for

Environment, Safety, and Health

under Contract DE-AC06-76RLO 1830

Pacific Northwest Laboratory

Operated for the U.S. Department of Energy

by Battelle Memorial Institute 


\title{
DISCLAIMER
}

This report was prepared as an account of work sponsored by an agency of the United States Government. Neither the United States Government nor any agency thereof, nor Battelle Memoriai Institute, nor any or their employees, makes any warranty, expressed or implied, or assumes any legal liability or responsibility for the accuracy, completeness, or usefulness of any information, apparatus, product, or process disclosed, or represents that its use would not in fringe privately owned rights. Reference herein to any specific commercial product, process, or service by trade name, trademark, manufacturer, or otherwise does not necessarily constitute or imply its endorsement, recommendation, or favoring by the United States Government or any agency thereof, or Battelle Memorial Institute. The views and opinions of authors expressed herein do not necessarily state or reflect those of the United States Government or any agency thereof, or Battelle Memorial Institute.

\author{
PACIFIC NORTHWEST LABORATORY \\ operated by \\ BATTELLE MEMORIAL INSTITUTE \\ for the \\ UNITED STATES DEPARTMENT OF EINERGY \\ under Contract DE-AC06-76RLO 1830
}

\begin{tabular}{|c|c|}
\hline \multicolumn{2}{|c|}{ Printed in the United States of America } \\
\hline \multirow{2}{*}{\multicolumn{2}{|c|}{$\begin{array}{l}\text { Available from } \\
\text { National Technical Information Service }\end{array}$}} \\
\hline & \\
\hline \multirow{3}{*}{\multicolumn{2}{|c|}{$\begin{array}{c}\text { United States Department of Commerce } \\
5285 \text { Port Royal Road } \\
\text { Springfield, Virginia } 22161\end{array}$}} \\
\hline & \\
\hline & \\
\hline \multirow{2}{*}{\multicolumn{2}{|c|}{$\begin{array}{l}\text { NTIS Price Codes } \\
\text { Microfiche A01 }\end{array}$}} \\
\hline & \\
\hline \multicolumn{2}{|c|}{ Printed Copy } \\
\hline & Price \\
\hline Pages & Codes \\
\hline $001-025$ & A02 \\
\hline $026-050$ & $\mathrm{~A} 03$ \\
\hline $051-075$ & A04 \\
\hline $076-100$ & A05 \\
\hline $101-125$ & $A 06$ \\
\hline $126-150$ & A07 \\
\hline $151-175$ & A08 \\
\hline $176-200$ & A09 \\
\hline $201-225$ & A010 \\
\hline $226-250$ & A011 \\
\hline $251-275$ & $\mathrm{~A} 012$ \\
\hline $276-300$ & $\mathrm{~A} 013$ \\
\hline
\end{tabular}


PNL -6583

UC -606

DOE RADIOLOGICAL CALIBRATIONS

INTERCOMPARISON PROGRAM:

RESULTS OF FISCAL YEAR 1987

F. M. Cummings

J. C. McDonald

June 1988

Prepared for
the U.S. Department of Energy
Assistant Secretary for
Environment, Safety, and Health
under Contract DE-ACO6-76RLO 1830

Pacific Northwest Laboratory

Richland, Washington 99352 


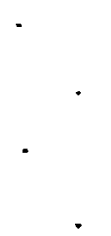


FOREWORD

The radiological calibration program is fundamental to radiation protection. The quality of a radiation protection program depends on maintaining standards for radiological calibration that are accurately traceable to national standards and for which measurements of verification may be routinely and precisely performed. The U.S. Department of Energy (DOE) Intercomparison Program, developed by the DOE Office of Nuclear Safety, has a goal to improve accuracy and precision in the measurement of radiological standards. Performing the intercomparison measurements helps identify areas requiring further attention by the participating laboratories, and communication is increased among individuals responsible for maintaining radiological standards. To the individual participant, the intercomparison program provides the opportunity to gain in understanding particular irradiation sources and facilities and to test transfer techniques not usually available in the participant's laboratory.

The measurement process allows the use of either state-of-the-art calibration equipment, which may be different from that used at the participant's laboratory, or a secondary standard set of beta sources described and specified in the International Standardization Organization (ISO) standard for beta dosimetry, ISO 6980 (1984).

Participation in this program by all DOE laboratories maintaining radiological standards is both welcomed and encouraged. We hope that the publication of the present and future annual reports will serve to both identify and maximize the benefits of the program.

E. J. Vallario, Acting Director

Radiological Controls Division

Office of Nuclear Safety

U.S. Department of Energy 


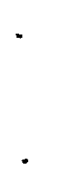




\section{EXECUTIVE SUMMARY}

Calibration measurements for personnel dosimetry purposes must be both accurate and consistent with national standards. In order to satisfy these requirements, the following methods are usually employed. In one case, a radiation source is sent to the National Bureau of Standards (NBS) for calibration and is returned to the laboratory to be used as a local standard. Another method involves the calibration of an instrument, such as an ionization chamber, by NBS. After calibration, this instrument is then used to measure the exposure rate delivered by radiation sources at the laboratory. Such calibrations by the NBS are essential, but they do not provide a complete check on the quality of the calibrations that are carried out by the individual laboratory. Additional measurements are necessary to assure the quality of such measurements. When laboratory staff are asked to carry out measurements with calibrated instruments and report results for evaluation, they are participating in a measurement quality assurance (MQA) program. Such a program tests not only the quality of the equipment but also the ability of the staff to correctly use and interpret the results obtained with the equipment. The NBS operates an MQA program with a selected number of calibration laboratories. Pacific Northwest Laboratory (PNL) participates in this MQA program even though NBS tests only $x$-ray and gamma-ray measurements. The U.S. Department of Energy (DOE) intercomparison program was designed specifically to include $x$-ray, gamma-ray, beta, and neutron calibrations for personnel dosimetry purposes. This program serves a need that is not being met by the NBS, and it provides documentation of the accuracy and uniformity of the radiological calibrations carried out in DOE facilities.

The results of the MQA intercomparisons that were carried out this year can be summarized as follows: 1) The average of the measurements of the gamma-ray exposure was only about $1 \%$ higher than the given gamma-ray exposure. This level of agreement is improved over that measured last year and is well within the $5 \%$ accuracy specified in the DOELAP standard. 2) The average of the measurements of beta dose rate was about $4 \%$ higher 
than the given dose, and this level of agreement is also within the $5 \%$ accuracy specification. 3) The average of the measurements of neutron tissue dose was about twice the given value. This discrepancy exceeds the 5\% accuracy specification, and its cause is under investigation.

The future directions that will be taken in this program include identifying the problems associated with the measurement of neutron sources, making further site visits to some DOE facilities to assist in conducting intercomparison measurements, and conducting a second calibration workshop during which information can be exchanged among personnel operating DOE calibrations laboratories. 


\section{ACKNOWLEDGMENTS}

The authors wish to thank J. M. Selby and G. W. R. Endres for reviewing this report and for their helpful suggestions. We also thank Peggy Upton for her patience in editing the report and Marianna Cross for typing it. 


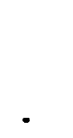




\section{CONTENTS}

FOREWORD ........................... . . i i

EXECUTIVE SUMMARY . . . . . . . . . . . . . . . . . V

INTRODUCTION ............................. 1

INTERCOMPARISON PROGRAM OPERATION . . . . . . . . . . . . 5

EQUIPMENT DESCRIPTION . . . . . . . . . . . . . . . 7

INSTRUMENT SET ................... 7

Electrometer .................. . 7

Thin-Walled Ionization Chamber for Photon Measurements . . 9

Tissue Equivalent Ionization Chamber for Neutron

Measurements .................. 10

Geiger-Mueller Counter .............. . 10

Extrapolation Ionization Chamber for Beta Measurements . . 11

Scaler/Ratemeter ................. 11

Battery High-Voltage Power Supply . . . . . . . . 11

Charge Checker............... 12

Procedures ................... 12

SECONDARY STANDARD BETA SOURCE SET . . . . . . . . . 12

CALCULATIONS ........................... 14

Instruments .................. 14

Beta Sources .................. 18

MEASUREMENT RESULTS . . . . . . . . . . . . . . . . 21

PROGRAM PROBLEMS AND IMPROVEMENTS..$\cdot$. . . . . . . . . . 25

CONCLUSIONS . . . . . . . . . . . . . . . . . . . 29

REFERENCES ......................... 31 


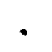




\section{FIGURES}

1 DOE Intercomparison Program Instrument Set . . . . . . . 8

2 The Keithley Electrometer, Front Panel . . . . . . . . 9

3 DOE Intercomparison Program Secondary Standard

Beta Source Set.................. 13

\section{TABLES}

1 Equipment Contained in the Intercomparison Instrument Set . . 8

2 Parameters Used to Calculate the Absorbed Dose

from the DOE Intercomparison Beta Sources . . . . . . . . 19

3 Parameters Used to Calcylate the Air Density Corrections,

$K_{A}, D=D_{0}\left(1+a x+b x^{2}\right)$ and $x=1-\rho / \rho_{0} \ldots . . . . . . .19$

4 Summary of Intercomparison Results Using the

Air Equivalent Ionization Chamber ............ 22

5 Summary of Intercomparison Results for Neutron Kerma

Rate Measurements ................. 23

6 Summary of Irradiations Performed Using the ${ }^{90} \mathrm{Sr}$ Source in the Secondary Standard Beta Set. . . . . . . . . . 24

7 Summary of Irradiations Performed Using the ${ }^{204} \mathrm{Tl}$ Source in the Secondary Standard Beta Set ............ 24

8 Summary of Irradiations Performed Using the ${ }^{147}$ Pm Source in the Secondary Standard Beta Set . . . . . . . . . 24 
. 
INTRODUCTION

During the fiscal years (FY) 1984 and 1985, as part of the Technical Guidelines for the Radiological Calibration Project, the Pacific Northwest Laboratory (PNL) ${ }^{(a)}$ conducted a study to evaluate the feasibility of operating a routine program for the intercomparison of radiological calibrations performed at U.S. Department of Energy (DOE) facilities. (b) The objectives of the intercomparison program are to 1) provide standard measurement techniques that allow DOE laboratories to assess and improve the accuracy of radiological calibration sources, 2) provide a data base for recommending improvements in calibration techniques and units generally applicable to all DOE facilities, and 3) provide a forum addressing problems and potential problems related to radiological calibrations.

To meet the objectives, a program under the DOE Laboratory Accreditation Program (DOELAP), was initiated during FY 1986 to routinely compare radiological calibrations. The program is managed and operated by PNL. A set of intercomparison instruments was made available to DOE laboratories on a monthly basis, and one secondary beta source set was made available to DOE laboratories on a bimonthly basis. Participants in the program used the instruments to perform dose or exposure measurements on their calibration sources, or they used the beta source to irradiate the instruments that calibrate their standards. The results of the measurements were forwarded to PNL for tabulating and comparing to calibration values established by PNL for the various instruments and beta sources. Participation by the DOE laboratories was voluntary; submission of measurement results was also voluntary, even though strict confidentiality was maintained regarding the originator of the results.

(a) PNL is operated for the U.S. Department of Energy by Battelle Memorial Institute under contract DE-ACO6-76RLO 1830.

(b) McDonald, J. C., P. L. Roberson, and F. M. Cummings. Intercomparison of Radiological Calibration Sources. A Pilot Study (Draft). Pacific Northwest Laboratory, Richland, Washington. 
To compare measurements from a wide variety of sources, four instruments were selected for inclusion in the instrument set. The four instruments and their respective uses are 1) a thin-walled ion chamber with build-up cap to measure the exposure rate from $x$-ray and gamma-ray sources, 2) a tissue equivalent ionization chamber to measure the absorbed dose rate from neutron sources, 3) a Geiger-Mueller (GM) counter to estimate the absorbed dose rate for photons in mixed neutron/gamma fields, and 4) an extrapolation ionization chamber to measure the absorbed dose rate from beta sources.

In addition, a set of beta sources including a $2-\mathrm{mCi}(74-\mathrm{MBq}){ }^{90} \mathrm{Sr} /{ }^{90} \mathrm{Y}$ source, a $0.5-\mathrm{mCl}(18.5-\mathrm{MBq}){ }^{204} \mathrm{Tl}$ source, and a $14.5-\mathrm{mCi}(536.5-\mathrm{MBq}){ }^{147} \mathrm{Pm}$ source was provided. The set also included an irradiation $\mathrm{jig}$ and a shutter with a controller/timer.

Instrument and source sets were scheduled for distribution to participants based on availability. There were two instrument sets, and scheduling was staggered such that one set was avaflable each month. The source set was available on a bimonthly basis.

Participants performed the desired measurements and irradiations, and returned the sets and results to PNL. The instruments were operationally checked and sent to the next participant. The measurement results were compared to PNL values and reported to each participant. This annual report summarizes the operation, results, problems, and improvements in the program.

The DOE benefits from the operation of the program in many ways. Some of these benefits include:

- The accuracy and credibility of radiological calibration are improved by frequent measurement and intercomparison.

- Common problems of a general nature are identified, allowing a DOE-wide approach in solving problems related to radiological calibrations.

- A radiological calibration workshop is planned to be held once every 2 years. This provides a forum in which to address the 
impact of proposed regulations on calibrations, such as changes in the neutron quality factor and changes resulting from the impact of calibrations on regulations,.e.g., the DOELAP performance results.

- The results and conclusions of this project directly support the DOELAP operational program and certain DOELAP research tasks.

This report presents the FY 1987 results of the radiological calibrations intercomparison program. The intercomparison operation is discussed, and the equipment is described, particularly the instrument set, the beta source set, and relevant calculations. Solutions to problems and improvements in the program are suggested, and conclusions are then introduced. 



\section{INTERCOMPARISON PROGRAM OPERATION}

The intercomparison program makes the instrument sets and beta source set available to the greatest number of participants possible during the fiscal year. The operation of the program is described below in chronological sequence.

1. An invitation to participate in the intercomparison is sent annually to those people at DOE laboratories who are primarily involved in performing or managing radiological calibrations. The invitation contains a short history of the intercomparison and a participation request form.

2. When a participation request form is received from a participant, the requested instrument set or beta set is scheduled as specified on the form. If a particular intercomparison set is unavailable at the requested time, the participant is notified in order to reschedule the intercomparison set.

3. Letters are sent to participants verifying the scheduled use of the intercomparison sets. A copy of this verification letter is included in each intercomparison set sent to a participant. The expected arrival of the set will occur during the second week of the scheduled month of participation.

4. The participant uses the intercomparison set on the calibration sources of his choice. At the conclusion of the measurements or irradiations, the set is returned to PNL so that its expected arrival occurs during the last week of the month after it was sent. Thus, the length of time a participant has the intercomparison set is always greater than 4 weeks.

5. Results of the measurements or irradiations are reported to PNL where those results are compared to reference values. The comparisons and the calculational methods are normally reported back to each participant within 6 weeks of the time their results were reported to PNL. 
At any time during the sequence, the participant may decide that the results are suspect and should not be reported. Because participation is voluntary, the use of the reported data has been left in control of the participant. All results, however, are strictly confidential between the PNL intercomparison program manager and the participating laboratory. 


\section{EQUIPMENT DESCRIPTION}

The equipment used in the DOE Radiological Calibrations Intercomparison Program includes two complete sets of intercomparison instruments and one set of secondary standard beta sources. The components of each set are described in the following sections.

\section{INSTRUMENT SET}

The instruments used in the intercomparison were the same as those used for the pilot intercomparison program, which was operated under Technical Guidelines for the Radiological Calibrations Project. These particular instruments were chosen for maximum flexibility of dose measurement from a variety of radiological sources, for their precision and stability, and for their simplicity of use and familiarity to the participants.

The specific pieces of equipment contained in each instrument set are listed in Table 1. The intended purpose of each piece of equipment is also provided in Table 1.

The chambers are calibrated using ${ }^{137}$ Cs in the PNL calibration facility. The exposure rates of the ${ }^{137}$ Cs source are traceable to the National Bureau of Standards (NBS) by means of transfer standards (ionization chambers). The electrometer is calibrated using a picoampere source, which is traceable to NBS from the Hanford Engineering Development Laboratory Calibration Program. The instruments are shown in Figure 1, and a description of each instrument is provided below.

\section{Electrometer}

The electrometer is a Keithley Model 614 multifunction meter (a) capable of measuring integral charge between $10^{-8}$ and $10^{-11}$ coulombs (C) and voltages between $10^{-4}$ and 20 volts $(V)$. It can operate on 110 VAC or on its integral battery pack. The display is 4-1/2 digits.

(a) Keithley Instruments, Cleveland, Ohio. 
TABLE 1. Equipment Contained in the Intercomparison Instrument Set

Piece of Equipment

Electrometer

Thin-walled ion chamber

Tissue equivalent ion chamber

Extrapolation ion chamber

Geiger-Mueller (GM) counter

Scaler/ratemeter

Battery high-voltage power supply

Charge checker
Intended Purpose

Measure and record integral charge from ionization chamber measurements

Measure exposure from photon calibration sources

Measure total kerma from neutron calibration sources

Measure the dose rate from bet calibration sources at $7 \mathrm{mg} / \mathrm{cm}^{2}$

Measure the component of dose resulting from photons created by a neutron calibration source

Record integral pulses from the GM counter and supply high voltage to the GM counter

Provide a stable bias voltage in 50 -volt steps from 0 to \pm 300 volts for use with ionization chambers

Provide a stable charge with which to check the electrometer operation

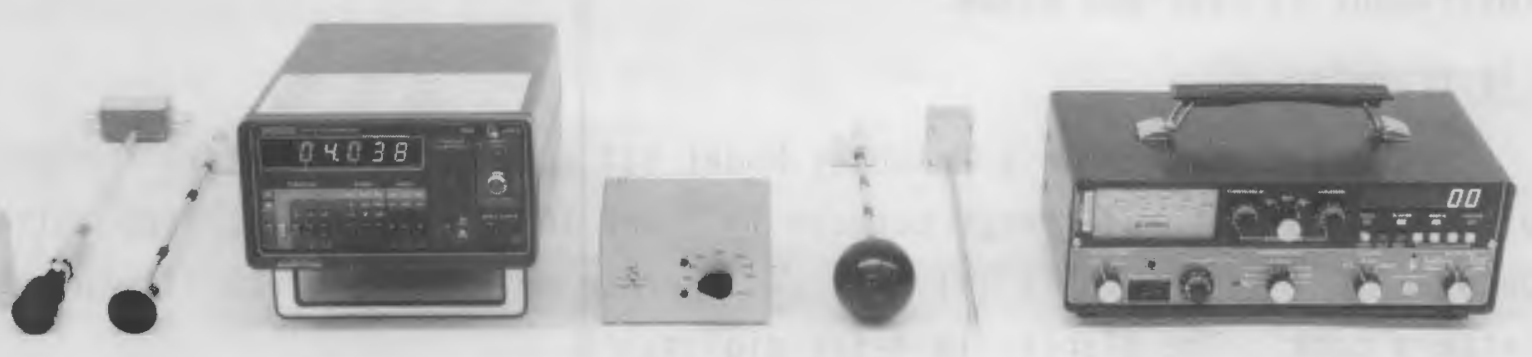

FIGURE 1. DOE Intercomparison Program Instrument Set 
The input/output connector is a triaxial connector. In addition, a triaxial-to-coaxial (triax-to-coax) adapter is provided, allowing the user to use low-noise coaxial signal cables for the ionization chambers. A 75- $\mathrm{ft}$ coaxial signal cable is also supplied in the instrument set.

The front panel of the Keithley electrometer is illustrated in Figure 2. The electrometer has been modified by the inclusion of a "run/hold" switch that "freezes" the display and allows timed measurements.

Thin-Walled Ionization Chamber for Photon Measurements

The ionization chamber chosen for photon measurements is a Capintec Model PM-30. (a) The chamber is constructed of air equivalent conducting plastic and has an active volume of $28 \mathrm{~cm}^{3}$. The response of the instrument for measuring exposure is nearly independent of the energy of the incident photons from $20 \mathrm{keV}$ to a few MeV. A Lucite build-up cap is provided so the chamber can be used for high-energy photons (137Cs and

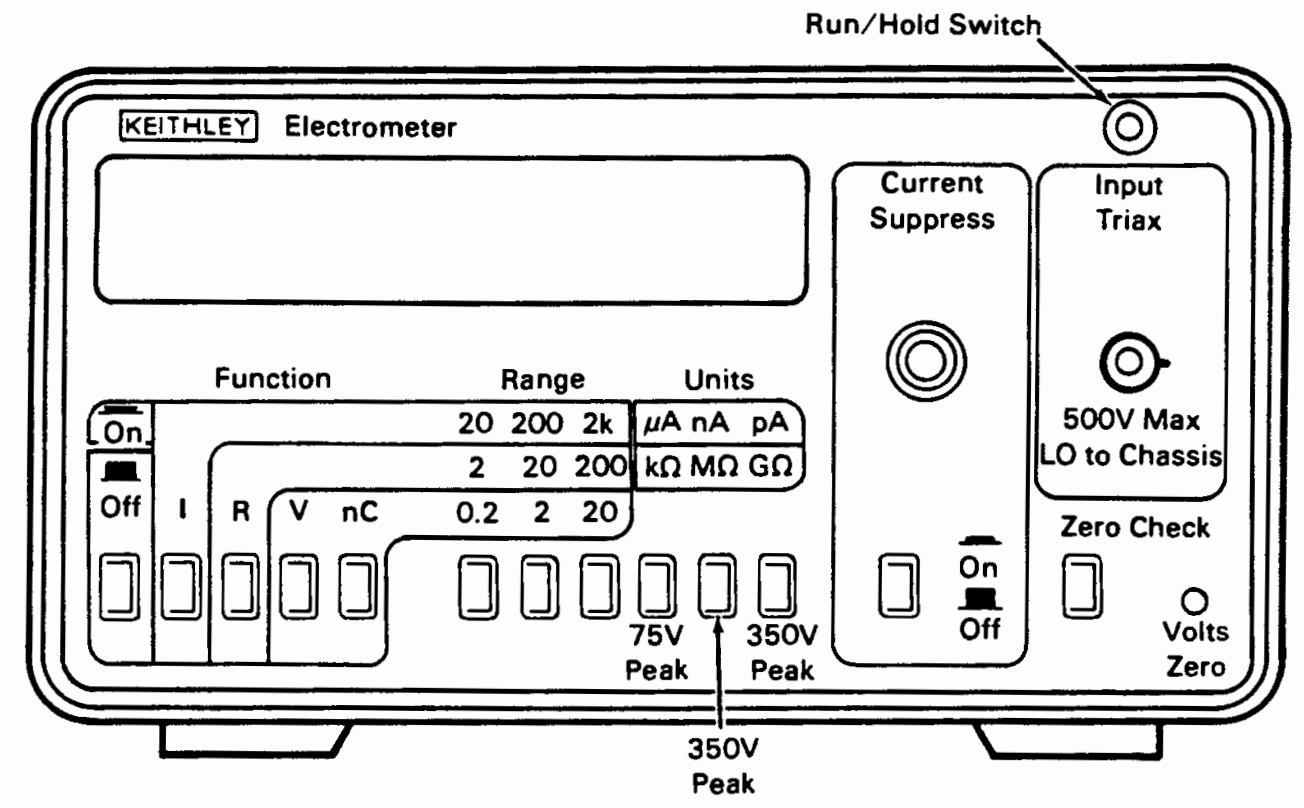

FIGURE 2. The Keithley Electrometer, Front Panel

(a) Capintec, Inc., Montvale, New Jersey.

- Trademark of the E. I. duPont de Nemours \& Company, Wilmington, Delaware. 
${ }^{60} \mathrm{Co}$ ). Without the build-up cap, the chamber may also be used to measure exposure rates from $x$-ray beams. The connector is a triaxial-BNC type that connects to a shop-built cable splitter. The connections on the cable splitter are BNC for the signal and MHV for the high voltage.

Tissue Equivalent Ionization Chamber for Neutron Measurements

The ionization chamber chosen for neutron measurements is a Far West Technology (FWT) (a) Model IC-80 tissue equivalent ionization chamber. The $80-\mathrm{cm}^{3}$ spherical chamber is constructed of A-150 tissue equivalent plastic and is usually operated with ambient air as the fill gas, rather than tissue equivalent counting gas. The signal output connector is a BNC type, and the high-voltage connector is an MHV type. The chamber is operated using $300-V$ high voltage. The signal is directed to the electrometer by means of a low-noise coaxial signal cable and a coax-to-triax adapter. The instrument is used in conjunction with a GM counter for neutron measurements. The ionization chamber measures total kerma. The GM counter, because of its low sensitivity to neutrons, is used to measure the kerma from photons. Geiger-Mueller Counter

The GM counter chosen to measure the photon contribution of kerma in a neutron field is an FWT model GM-2 energy-compensated GM counter. (a) The detector is a sma11, 0.48-cm-diameter GM tube with an active volume of $0.12 \mathrm{~cm}^{3}$. The fill gas is neon, quenched with a halogen-quenching agent. The tube wall is a nonchromium alloy. The detector is enclosed in an energy flattening shield to eliminate the normal low-energy photon response characteristic. The photon energy response of the GM counter is $\pm 10 \%$ from $70 \mathrm{keV}$ to $2 \mathrm{MeV}$. The signal output through a BNC-type connector is routed to a read-out device (scaler) through the coaxial signal cable. The counter is operated at $+750 \mathrm{~V}$. The scaler and high-voltage power supply for the GM counter were supplied as part of the intercomparison set.

(a) Far West Technology, Goleta, California. 


\section{Extrapolation Ionization Chamber for Beta Measurements}

The chamber chosen for determining dose rates from beta sources is an FWT Model EIC-1 tissue equivalent plastic extrapolation ionization chamber. ${ }^{(a)}$ The device is a parallel-plate-type ionization chamber with a continuously variable volume from approximately 0.1 to $1.4 \mathrm{~cm}^{3}$. The front entry window has a density thickness of $6.9 \mathrm{mg} / \mathrm{cm}^{2}$. The collecting electrode was modified by the manufacturer from a $1-$ to a $2-\mathrm{cm}$ diameter to increase the sensitivity. The output is routed through a BNC connector to the electrometer using low-noise coaxial signal cable and a coax-to-triax adapter. The recommended high voltage is 50 volts per revolution of the outer wall of the chamber ( 1 revolution $=$ approximately $1-m m$ increase in gap).

\section{Scaler/Ratemeter}

The Bicron scaler/ratemeter ${ }^{(b)}$ is a microprocessor-controlled, standalone counter with a seven-decade light-emitting diode (LED) display. This model features a crystal-controlled time base, preset time, and preset count modes, including integral count, count rate, and elapsed time. In addition, an internal high-voltage supply is capable of providing 0 to 2000 volts for GM counters. The instrument can operate on $110 \mathrm{VAC}(60 \mathrm{~Hz})$ or on its integral battery supply.

The input/output connectors are both coaxial, with a BNC type for the signal input and an MHV type for the high-voltage output.

Battery High-Voltage Power Supply

The battery high-voltage power supply is a box containing a 300-volt battery. A switch is included to select either "polarity" or an "off" position. A range switch allows selected voltages from 0 to 300 volts in discrete steps of 50 volts. At the "zero" voltage setting, probe connectors have been installed to allow for a voltage check under load. The output connector is a coaxial MHV connector.

(a) Far West Techology, Goleta, California.

(b) Bicron Corporation, Newbury, Ohio. 


\section{Charge Checker}

Also included in the instrument set is an electronic test circuit for verifying the stability of the electrometer. A mercury battery is used to charge a polystyrene capacitor. Both of the components are stable and produce a charge that is also quite stable over time. This charge pulse monitors the stability of the electrometer's response.

\section{Procedures}

Operating procedures detailing the description and use of the instruments are included in each instrument set. The procedures are updated several times during the year to clarify and address specific characteristics of each measurement. Included in the procedures are graphic illustrations of the electrical connections for each instrument.

\section{SECONDARY STANDARD BETA SOURCE SET}

The secondary standard beta source set (referred to as the beta set in this report) consists of three beta-emitting sources and an irradiation apparatus, shown in Figure 3. The set, Model BSS.1, was purchased from Amersham ${ }^{(\mathrm{a})}$ and includes a $2-\mathrm{mCi}(74-\mathrm{MBq}){ }^{90} \mathrm{Sr} /{ }^{90} \mathrm{Y}$ source, a $0.5-\mathrm{mCi}$ $(18.5-\mathrm{MBq}){ }^{204} \mathrm{Tl}$ source, and a $14.5-\mathrm{mCl}(536.5-\mathrm{MBq}){ }^{147} \mathrm{Pm}$ source. The sources are secured in a lead pig (for shipping) inside a Department of Transportation (DOT)-7A overpack. For irradiations, a source is removed from the pig using the supplied source handling tool and is secured in the irradiation jig. The shutter of the $j$ ig is controlled using a microprocessor-based controller/timer that is part of the set. Other equipment includes beam-flattening filters, reference-distance rods, a jig stand, and instructions for use. The same set is designed to follow the specifications for the series 1 source set of the International Standardization Organization (ISO) standard on beta dosimetry, ISO 6980 (ISO 1984).

(a) Amersham Corporation, Arlington Heights, Illinois. 


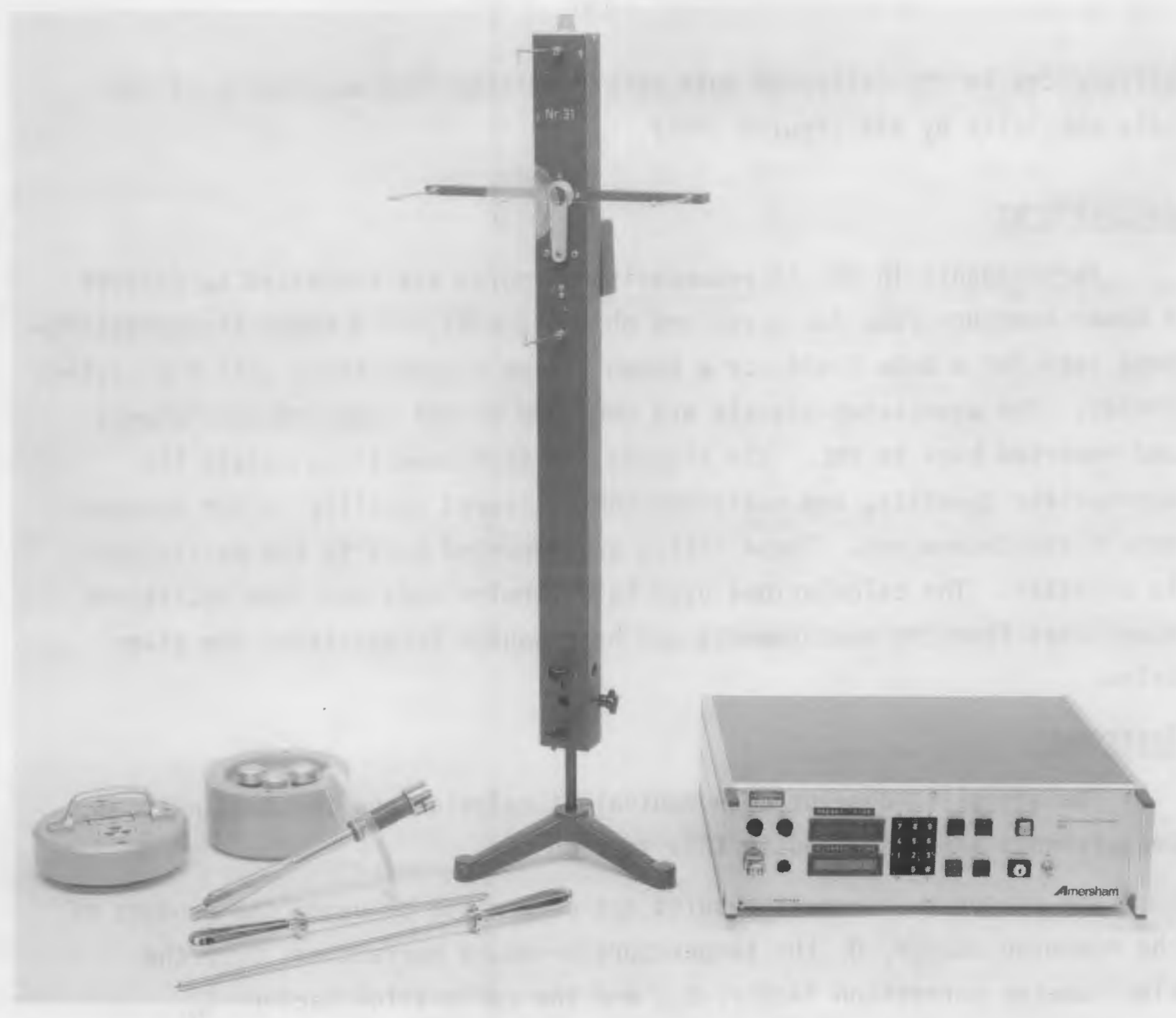

FIGURE 3. DOE Intercomparison Program Secondary Standard Beta Source Set

The dose rates of the sources have been determined using a PhysikalischTechnische Bundesanstalt (PTB)-type extrapolation ionization chamber calibrated using a similar beta secondary standard set at PNL, which was calibrated at the PTB and checked under the measurement quality assurance program between PNL and the NBS. Reference dose rates are taken to be at a depth of $7 \mathrm{mg} / \mathrm{cm}^{2}$ and a distance of $30 \mathrm{~cm}$ from the source for ${ }^{90} \mathrm{Sr} /{ }^{90} \mathrm{Y}$ and ${ }^{204} \mathrm{Tl}$. The dose rate from ${ }^{147} \mathrm{Pm}$ is referenced to a depth of $7 \mathrm{mg} / \mathrm{cm}^{2}$ in tissue, at a distance of $20 \mathrm{~cm}$ from the source. The dose rate is also normalized to standard temperature, pressure, and humidity to allow for 
differences in the delivered dose rate resulting from absorption of the beta particles by air (Pruftt 1985).

\section{CALCULATIONS}

Participants in the intercomparison program are requested to deliver a known exposure rate for $x$-ray and photon fields, or a known tissue absorbed dose rate for a beta field, or a known tissue neutron kerma rate for neutron fields. The associated signals are recorded on the supplied data sheets and reported back to PNL. The signals are then used to calculate the appropriate quantity, and ratios of the delivered quantity to the measured result are determined. Those ratios are reported back to the participant in a letter. The calculations used to determine dose and dose equivalent quantities from the measurements and beta source irradiations are given below.

Instruments

The signal-to-dose or dose equivalent calculations for the instrument measurements are described in this section.

The photon measurement results are determined by using the product of the measured charge, $Q$, the temperature/pressure correction, $C_{t p}$, the electrometer correction factor, $C_{e}$, and the calfibration factor, $C_{\boldsymbol{\gamma}}$.

$$
X=Q \cdot C_{t p} \cdot C_{e} \cdot C_{\gamma}
$$

where $X=$ the integral exposure in $R$ (coulombs $/ \mathrm{kg}$ )

$Q=$ the net collected charge in coulombs

$c_{t p}=$ the correction for temperature/pressure

$C_{e}=$ electrometer calibration factor

$\mathrm{C}_{\boldsymbol{\gamma}}=$ the PNL calibration constant.

For the beta measurements, the standard extrapolation chamber formula from Appendix C of ISO Standard 6980 (ISO 1984) is used. 


$$
\dot{D}_{t}=S_{T, A} \frac{\bar{W}}{e} \times \frac{1}{b \rho_{A}}\left(\frac{d I}{d x}\right)_{x \rightarrow 0}
$$

where $\quad \dot{D}_{t}=$ the absorbed dose rate to tissue at $7 \mathrm{mg} / \mathrm{cm} 2$ in $\mathrm{rad}$ (Gy) $S_{T, A}=$ the ratio of the average mass collision stopping powers of tissue and of air

$\frac{W}{e}=$ The quotient of the mean energy, $w$, expended in dry air per ion formed and the elementary charge, e

$b=$ the effective area of the collecting electrode

$\rho_{A}=$ the density of air at standard temperature and pressure (STP)

$\left(\frac{d I}{d x}\right)_{x \rightarrow 0}=$ the limiting value of the quotient of the corrected mean ionization current, $I$, produced in the chamber by the chamber depth as this chamber depth $x$ approaches 0 . $\left(\frac{d I}{d x}\right)_{x \rightarrow 0}$ is calculated from the slope of the function $I(x)$

$I=$ the mean collected ionization currents (corrected to STP conditions) for positive and negative bias voltages.

For the FWT extrapolation chamber, the area of the collecting electrode is $3.14 \mathrm{~cm}^{2}$. The ratio of $\bar{W} / e=33.85 \mathrm{eV} /$ ip (joules/coulomb). The air density, $\rho_{A}$, is $0.001197 \mathrm{~g} / \mathrm{cm}^{2}$ at $22^{\circ} \mathrm{C}\left(295^{\circ} \mathrm{K}\right)$ and $760 \mathrm{mmH}$ $(101.3 \mathrm{kPa})$. No further corrections are applied to adjust the signals for effects listed in Appendix C for ISO 6980 (ISO 1984).

The neutron measurements require two detectors: a tissue equivalent plastic ionization chamber for total (gamma plus neutron) kerma and a GM counter for gamma exposure. The following calculation for tissue kerma rate is taken from International Commission on Radiation Units and Measurements (ICRU) Report 26, Neutron Dosimetry for Biology and Medicine (1977) and from American Association of Physicists in Medicine (AAPM) Report 7, Protocol 
for Neutron Beam Dosimetry (1980). The first step is to calculate the response of the tissue equivalent chamber and $G M$ counter by:

$$
\begin{aligned}
& \dot{R}_{T}=\dot{Q} \cdot c_{T} \\
& \dot{R}_{u}=\dot{N} \cdot c_{u}
\end{aligned}
$$

where $\dot{R}_{T}=$ the response of the tissue equivalent ionization chamber from neutrons and photons (roentgen $\cdot \sec ^{-1}$ )

$\dot{Q}=$ the average current from the tissue equivalent ionization chamber corrected for air density and electrometer calibration (coulomb $\cdot \mathrm{sec}^{-1}$ )

$C_{T}=$ the ionization chamber calibration constant (roentgen $\cdot$ coulomb $^{-1}$ )

$\dot{R}_{u}=$ the response of the GM counter from photons (roentgen $\cdot \sec ^{-1}$ )

$\dot{N}=$ the average pulse rate collected using the GM counter (pulses $\cdot \sec ^{-1}$ )

$c_{u}=$ the GM calibration constant (roentgen $\cdot$ pulse ${ }^{-1}$ ).

In order to calculate a neutron kerma rate to tissue, two assumptions are made about the GM counter. First, response of the GM counter is assumed independent of photon energy (e.g.., the number of pulses per roentgen is equivalent for photons with different energies over a wide range of energies). The energy response of the counter quoted by the manufacturer is $1.00 \neq 0.10$ for photons with energies between 0.07 and $2.0 \mathrm{MeV}$. The intention is that this response be verified in FY 1988.

The second assumption is that the response of the GM counter to neutrons is negligible. Ongoing work at the PTB indicates that the neutron response 
(pulses per rad, tissue kerma) is less than $2 \%$ of the photon response for small commercially available GM tubes.

The neutron kerma rate in tissue is then calculated by:

$$
\dot{D}_{n}=\left(\dot{R}_{T}-\dot{R}_{U}\right) \cdot \frac{\left(S_{w_{1} g}\right)_{N}}{\left(S_{w, g}\right)_{c}} \cdot \frac{\bar{W}_{N}}{\bar{W}_{c}} \cdot \frac{K_{N}}{K_{c}} \cdot A_{w c} \cdot f_{t, c}
$$

where $\quad \dot{D}_{n}=$ neutron kerma rate in tissue (rad. $\left.\sec ^{-1}\right)$

$\left(S_{w, g}\right)_{x}=$ ionization chamber gas-to-wall kerma conversion factor for the secondary charged particles created by the neutron field $(x=N)$ or by the calibration source $(x=C)$

$\bar{W}_{x}=$ average energy required to create an ion pair in the chamber gas by secondary charged particles created by the neutron field $(x=N)$ or by the calibration source $(x=c)$

$\mathrm{K}_{\mathrm{N}}=$ neutron kerma factor ratio for ICRU muscle tissue relative to A-150 tissue equivalent (TE) plastic

$K_{C}=$ quotient of mass energy absorption coefficients for ICRU muscle tissue to A-150 TE plastic for the photons from the calibration source

$A_{w C}=$ attenuation and scattering correction factor for the calibration source for the TE chamber of equilibrium wall thickness

$f_{t, c}=$ ICRU muscle tissue kerma-to-exposure conversion factor for the photons from the calibration source.

The parameters in the kerma calculation are dependent on the neutron energy spectrum of the neutron field and on the calibration source. Because ${ }^{137}$ Cs is the calibration source, the following values have been adopted: 


\begin{tabular}{lcll}
\multicolumn{1}{c}{ Parameter } & \multicolumn{1}{c}{ Value } & & Reference \\
\cline { 1 - 1 }$\left(S_{W, g}\right)_{C}(A-150 /$ air $)$ & 1.10 & & Hubbell 1982 \\
$\bar{W}_{C}($ air $)$ & $33.8(\mathrm{~J} /$ coul $)$ & ICRU 1979 \\
$K_{C}($ air $)$ & 1.002 & Hubbell 1982 \\
$A_{W C}($ (A-150) & 1.026 & Hubbell 1982 \\
$f_{t, g}$ & 0.961 & Hubbell 1982
\end{tabular}

Beta Sources

The delivered doses from the beta sources in the secondary standard beta source set are calculated according to Böhm (1986):

$$
D=\dot{D}_{r} \cdot t \cdot K_{Z} \cdot K_{A} \cdot K_{F}
$$

where $D=$ the delivered dose in rad (Gy)

$$
\begin{aligned}
\dot{D}_{r}= & \text { the reference dose rate at } 7 \mathrm{mg} / \mathrm{cm}^{2} \text {, the reference distance at } \\
& \text { the reference calibration date } \\
t= & \text { the irradiation time } \\
\mathrm{K}_{Z}= & \text { the exponential decay correction to the source strength } \\
\mathrm{K}_{\mathrm{A}}= & \text { the air density correction to the dose because of temperature } \\
& \text { and pressure variations } \\
\mathrm{K}_{\mathrm{F}}= & \text { the air density correction to the dose because of humidity } \\
& \text { variations. }
\end{aligned}
$$

The values of $K_{Z}$ and $K_{F}$ currently adopted for the beta sources are contained in Table 2. In addition, the delivered doses are corrected for variations in air density, $K_{A}$, using the following algorithm from Pruitt (1985):

$$
D=D_{0}\left(1+a x+b x^{2}\right)
$$


where $\quad D=$ reference dose at $22^{\circ}\left(295^{\circ} \mathrm{K}\right)$ and 760 torr $(101.3 \mathrm{kPa})$

$D_{0}=$ the delivered dose

$a, b=$ coefficients listed in Table 3

$x=1-\rho / \rho_{0}$

$\rho=$ air density during the irradiation

$\rho_{0}=$ air density at the reference temperature and pressure.

TABLE 2. Parameters Used to Calculate the Absorbed Dose from the DOE Intercomparison Beta Sources
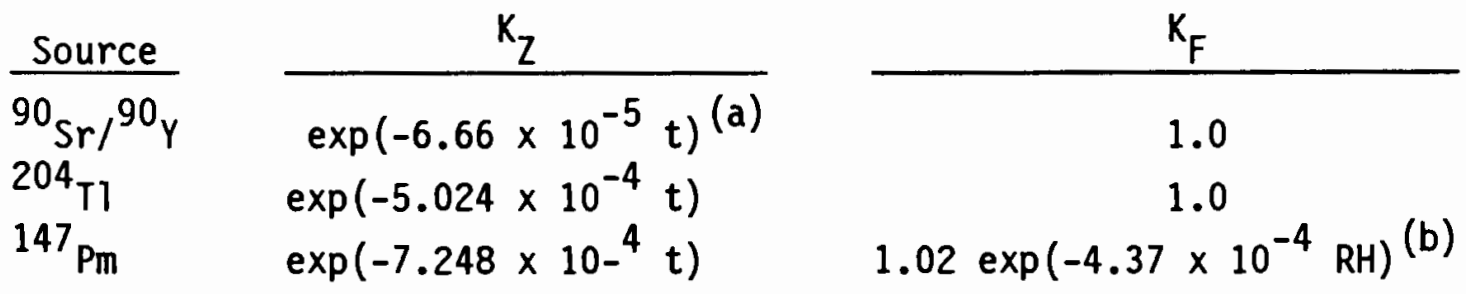

(a) $t$ is time (in days) that has elapsed between the calibration date and the irradiation date.

(b) RH is the relative humidity in percent.

TABLE 3. Parameters Used to Calculate the Air Density Corrections, $K_{A}$, $D=D_{0}\left(1+a x+b x^{2}\right)$, and $x=1-\rho / \rho_{0}$

\begin{tabular}{|c|c|c|c|c|}
\hline Nuclide & $\begin{array}{c}\text { Nominal Activity } \\
(\mathrm{M} \mathrm{Bg})\end{array}$ & $\begin{array}{l}\text { Reference_Depth } \\
\left(\mathrm{mg}-\mathrm{cm}^{-2}\right) \\
\end{array}$ & a & $b$ \\
\hline & 518 & 7 & 3.54 & 19.79 \\
\hline & 18.5 & 7 & 0.13 & -0.33 \\
\hline${ }^{90} \mathrm{Sr}_{+}{ }^{90} \mathrm{Y}$ & 74 & 7 & -0.05 & -0.18 \\
\hline
\end{tabular}




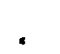

. 


\section{MEASUREMENT RESULTS}

During FY 1987, 10 laboratories requested the intercomparison instrument sets and 5 laboratories requested the secondary standard beta set. Six of the participating laboratories using instrument sets performed measurements. The other 4 participants encountered unforeseen problems with staffing and facility availability and were unable to complete the measurements. Four of the 5 participants using the beta set performed irradiations.

The instruments were used to intercompare calibration fields associated with ${ }^{137} \mathrm{Cs},{ }^{60} \mathrm{Co}$, and ${ }^{239}$ PuBe sources. None of the participants chose to use instruments contained in the intercomparison set to perform measurements in $x$-ray beams or in fields produced by isotopic beta sources.

The results of the photon measurements are summarized in Table 4. The average and one standard deviation of the delivered-to-measured exposure rate ratios was $1.01 \neq 0.04$. The results indicate excellent agreement and show a marked improvement over results obtained last year.

The results of the neutron measurements are summarized in Table 5. The average and one standard deviation of the delivered-to-measured kerma rate ratios was $2.16=0.94$. Participant $B$ performed the four measurements on a PuBe source in an irradiation well. The measurements were performed at decreasing depths, so the fourth measurement (ratio $=1.48$ ) was made closer to the source than the first measurement (ratio $=3.80$ ). A factor of 0.106 was used to convert the delivered neutron dose equivalent rate to a kerma rate based on quoted values for kerma factor and dose equivalent factors for PuBe (Nachtigall 1967). The differences point to a fundamental problem regarding neutron calibration sources which will be discussed in the next section. 
TABLE 4. Summary of Intercomparison Results Using the Air Equivalent Ionization Chamber

\begin{tabular}{|c|c|c|}
\hline Participant & Source & $\begin{array}{c}\text { Ratio } \\
\text { Delivered/Measured }\end{array}$ \\
\hline \multirow[t]{3}{*}{ A } & ${ }^{60} \mathrm{Co}$ & 0.98 \\
\hline & ${ }^{60} \mathrm{Co}$ & 0.99 \\
\hline & ${ }^{137} \mathrm{Cs}$ & 0.99 \\
\hline \multirow[t]{11}{*}{ B } & ${ }^{60} \mathrm{Co}$ & 1.03 \\
\hline & ${ }^{60} \mathrm{Co}$ & 1.09 \\
\hline & ${ }^{60} \mathrm{Co}$ & 1.07 \\
\hline & ${ }^{60} \mathrm{Co}$ & 1.08 \\
\hline & ${ }^{60} \mathrm{CO}$ & 0.99 \\
\hline & ${ }^{60} \mathrm{Co}$ & 1.01 \\
\hline & ${ }^{60} \mathrm{Co}$ & 1.02 \\
\hline & ${ }^{60} \mathrm{Co}$ & 1.00 \\
\hline & ${ }^{60} \mathrm{CO}$ & 0.97 \\
\hline & ${ }^{60} \mathrm{Co}$ & 0.98 \\
\hline & ${ }^{60} \mathrm{Co}$ & 0.99 \\
\hline c & ${ }^{137} \mathrm{Cs}$ & 0.95 \\
\hline \multirow[t]{3}{*}{ D } & ${ }^{137} \mathrm{Cs}$ & 1.00 \\
\hline & ${ }^{137} \mathrm{Cs}$ & 0.99 \\
\hline & ${ }^{137} \mathrm{Cs}$ & 0.98 \\
\hline \multirow[t]{2}{*}{$\mathrm{E}$} & ${ }^{137} \mathrm{Cs}$ & 1.02 \\
\hline & ${ }^{137} \mathrm{Cs}$ & 1.01 \\
\hline \multirow[t]{2}{*}{$F$} & $\begin{array}{l}\text { not yet } \\
\text { reported }\end{array}$ &.-- \\
\hline & Standarc & $\begin{array}{rr}\text { Average } & 1.01 \\
\text { eviation } & 0.04\end{array}$ \\
\hline
\end{tabular}


TABLE 5. Summary of Intercomparison Results for Neutron Kerma

\begin{tabular}{|c|c|c|c|}
\hline Participant & Source & Deliver & $\begin{array}{l}\text { Ratio } \\
\text { ed/Measured }\end{array}$ \\
\hline \multirow[t]{4}{*}{$B$} & PuBe & & 3.80 \\
\hline & PuBe & & 2.30 \\
\hline & PuBe & & 1.56 \\
\hline & PuBe & & 1.48 \\
\hline D & PuBe & & 2.53 \\
\hline \multirow[t]{3}{*}{$E$} & PuBe & & 1.28 \\
\hline & & Average & 2.16 \\
\hline & Standa & Deviation & 0.94 \\
\hline
\end{tabular}

(a) The following parameters were used to calculate neutron kerma rates:

$\left(S_{w, g}\right)_{n} 1.157$ (AAPM 1980)

$\bar{W}_{n} 31.0$ (ICRU 1979)

$K_{n} 0.977$ (Caswell, Coyne, and Randolph 1982 for 4.6 MeV neutrons)

The data from irradiations performed using the secondary standard beta set are summarized in Tables 6,7, and 8 . The averages and one standard deviations of the ratios of measured absorbed dose rates to delivered were $1.01 \pm 0.07$ for ${ }^{90} \mathrm{Sr}, 1.15 \pm 0.21$ for ${ }^{204} \mathrm{Tl}$, and 1.09 for ${ }^{147} \mathrm{Pm}$. The agreement of measurements on the ${ }^{90} \mathrm{Sr}$ source continues to be good, but the range of the accuracy of measurement is larger than desired. The measurement performed by participant $C$ indicates that good agreement may be achieved on low-energy, low-output sources. 
IABLE 6. Summary of Irradiations Performed Using the ${ }^{90} \mathrm{Sr}$ Source in the Secondary Standard Beta Set

\begin{tabular}{cccc} 
Participant & & Source & \multicolumn{1}{c}{$\begin{array}{c}\text { Ratio } \\
\text { Delivered/Measured }\end{array}$} \\
\cline { 3 - 4 } $\mathrm{C}$ & & ${ }^{90} \mathrm{Sr}$ & 1.09 \\
$\mathrm{G}$ & & ${ }^{90} \mathrm{Sr}$ & 0.98 \\
$\mathrm{H}$ & ${ }^{90} \mathrm{Sr}$ & 0.95 \\
& ${ }^{90} \mathrm{Sr}$ & not yet received \\
& One Standard Deviation & 0.07
\end{tabular}

TABLE 7. Summary of Irradiations Performed Using the ${ }^{204} \mathrm{TI}$ Source in the Secondary Standard Beta Set

\begin{tabular}{|c|c|c|}
\hline Participant & Source & $\begin{array}{c}\text { Ratio } \\
\text { Delivered/Measured }\end{array}$ \\
\hline c & ${ }^{204} \mathrm{Tl}$ & 1.00 \\
\hline G & ${ }^{204} \mathrm{TI}$ & 1.30 \\
\hline \multirow[t]{2}{*}{ H } & ${ }^{204} \mathrm{TI}$ & not yet received \\
\hline & Standard & $\begin{array}{l}\text { erage } \\
\text { ation }\end{array}$ \\
\hline
\end{tabular}

TABLE 8. Summary of Irradiations Performed Using the ${ }^{147} \mathrm{Pm}$ Source in the Secondary Standard Beta Set

\begin{tabular}{cccc} 
Participant & & $\frac{\text { Source }}{\text { Ratio }}$ & \multicolumn{2}{c}{$\begin{array}{c}\text { Delivered/Measured } \\
H\end{array}$} & ${ }^{147}{ }_{\mathrm{Pm}}$ & 1.09 \\
$H$ & ${ }^{147} \mathrm{Pm}$ & not yet recelved \\
Overage & 1.09
\end{tabular}




\section{PROGRAM PROBLEMS AND IMPROVEMENTS}

Problems encountered during FY 1986 were largely overcome in FY 1987 as equipment was modified to clarify and simplify operation of the instruments. Several instances of equipment failures were easily remedied as a result of the simplicity of instrumentation in the intercomparison sets.

In addition, changes were made to reduce electronic noise, or "leakage," providing increased precision of the measurements.

During FY 1987, two problems of general nature emerged. The first concerns measurement quantities and transfer quantities associated with neutron calibration fields. Neutron sources are calibrated at NBS in a manganese sulfate bath to directly measure the neutron emission rate. Unfortunately, the regulatory quantity of reference is dose equivalent. The neutron dose equivalent field associated with any neutron source will be modified by the geometry and scatter conditions under which it is employed. This is a problem at the national level because there is no instrument that can be used as a transfer standard for determining neutron dose equivalent.

The tissue equivalent proportional counter can directly measure neutron kerma in tissue equivalent plastic. The technique has been developed by DOE for other applications that pertain to field measurements of personnel dose. A two-phase, two-year program of evaluation and optimization/ implementation could provide the DOE community with the benefit of a portable neutron calibration transfer instrument. Before embarking on this program, a consensus of opinion should be elicited from a panel composed of DOE calibration personnel.

The second problem lies in the decision as to which type of instrument or measurement technique should be used for calibrating beta sources. Within the DOE community, there is no current agreement regarding this choice. Several laboratories have begun to use extrapolation chambers but find them difficult to use on low output beta calibration sources. Some 
of the participants are performing intercomparisons with personnel dosimeters.

The Physikalisch-Technische Werkstadt (PTW) extrapolation chamber has been designated by the PTB as the reference instrument for beta radiations in Germany. Böhm (1986) has documented the technique and all appropriate measurement parameters. The solution to beta source calibration problems is to include a PTW extrapolation chamber in each instrument set, or to specify that dose rates from beta calibration sources be routinely verified using a PTW extrapolation chamber. Again, a consensus of opinion from a panel composed of DOE calibrations personnel should be used to evaluate the solution and suggest methods of implementation.

These two problems will not likely be solved in the near future. However, part of the mission of the intercomparison program is to call attention to these problems and acquaint the DOE calibrations community with the most appropriate options to the problems, as perceived by the program.

To improve the intercomparison program during FY 1988, two DOE sites will be visited, the inclusion of dosimeters with the instrument sets will be evaluated, and the program will make arrangements for international participation.

Two sites will be visited where two or more participants are in proximity. The purpose of the visits will be to increase communication among calibrations personnel, to clarify operating procedures, and to discuss calibrations issues. The goal of the measurement quality assurance (MQA) program is to verify the quality of the entire measurement process. This is facilitated by onsite observation of the measurements. Several facilities have requested such visits. Results of the discussions will be summarized in trip reports and in the next annual report. Follow-up with participants will be increased to better understand reasons for their levels of performance and to provide assistance where needed.

Dosimeters were used in the intercomparison pilot study with limited success. Because the goal of the intercomparison program is to increase 
uniformity of calibrations, dosimeters should again be included in the instrument sets to investigate the sources of imprecision in dosimeter results and to gain some understanding of magnitude of imprecision in dosimeter calibrations at tertiary calibration facilities.

In addition, instruments will be sent to a European laboratory that has been identified as a national center for radiological standards. The purpose of the international participation will be to increase communication between the European and U.S. calibration communities. The benefit will be to relate U.S. standards to European standards. The U.S. calibrations community and the DOE regulatory body will gain information to further support established policies regarding the regulation of personnel dose and to support changes in national policies proposed by the DOE. 


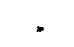

- 


\section{CONCLUSIONS}

The results of FY 1987 operation of the DOE Radiological Calibrations Intercomparison Program indicate a marked improvement over those of FY 1986. An increased number of measurements were performed, and agreement between participant measurements and reference quantities was distinctly better.

The results of the MQA intercomparisons that were carried out this year can be summarized as follows: 1) The average of the measurements of the gamma-ray exposure was only about $1 \%$ higher than the given gamma-ray exposure. This level of agreement is improved over that measured last year and is well within the $5 \%$ accuracy specified in the DOELAP standard. 2) The average of the measurements of beta dose rate was about $4 \%$ higher than the given dose, and this level of agreement is also within the $5 \%$ accuracy specification. 3) The average of the measurements of neutron tissue dose was about twice the given value. This discrepancy exceeds the 5\% accuracy specification, and its cause is under investigation.

A workshop was held under the auspices of the Technical Guidelines Program. This workshop, held in Richland, Washington in October 1986, provided a forum for the participants to discuss calibration issues and to communicate individual solutions to calibration problems. Comments were received regarding the beneficial aspects of the workshop. Overall, the workshop is viewed by the DOE calibrations community as a useful vehicle for progress toward standardization.

The intercomparison program has increased awareness of the importance of accurate and precise radiological calibrations, particularly in association with the DOE Laboratory Accreditation Program (DOELAP). Participants in the program have suggested changes, which have been subsequently implemented, thus allowing the DOE calibrations community as a group to design the intercomparison program. This cooperation is leading to a consistent approach to solving problems associated with radiological calibrations. 
- 


\section{REFERENCES}

American Association of Physicists in Medicine (AAPM). 1980. Protocol for Neutron Beam Dosimetry. AAPM Report No. 7, American Institute of Physics, New York, New York.

Böhm, J. 1986. The National Primary Standard of the PTB for Realizing the Unit of the Observed Dose Rate to Tissue for Beta Radiation.

Physikalisch-Technische Bundesanstalt (PTB) Report Bericht Dos-13. ISSN 0172-7095, Physikalisch-Technische Bundesanstalt, Braunschweig, West Germany.

Caswell, R. S., J. J. Coyne, and M. L. Randolph. 1982. "Kerma Factors of Elements and Compounds for Neutron Energies Below $30 \mathrm{MeV} . "$ Int. J. of Appl. Radiat. and Isot. 33(11):1227-1262.

Hubbe11, J. H. 1982. "Photon Mass Attenuation and Energy Absorption Coefficients from $1 \mathrm{keV}$ and $20 \mathrm{MeV} . "$ Int. J. of Appl. Radiat. and Isot. $33(11): 1269-1290$.

International Commission on Radiation Units and Measurements (ICRU). 1977. Neutron Dosimetry for Biology and Medicine. ICRU Report No. 26, International Commission on Radiation Units and Measurements, Washington, D.C.

International Commission on Radiation Units and Measurements (ICRU). 1979. Average Energy Required to Produce an Ion Pair. ICRU Report No. 31, International Commission on Radiation Units and Measurements, Washington, D.C.

International Standardization Organization (ISO). 1984. Reference Beta Radiations for Calibrating Dosemeters and Doseratemeters and for Determining Their Response as a Function of Beta Radiation Energy. IS0 69801984(E), International Organization for Standardization, Geneva, Switzerland.

Nachtigal1, D. 1967. "Average and Effective Energies, Fluence-Dose Conversion Factors and Quality Factors of the Neutron Spectra of Some $(a, n)$ Sources. Health Physics. 13(2):213-219.

Pruitt, J. S. 1985. "The Effect of Altitude on Beta Ray Source Calibrations." Radiation Protection Dosimetry. 11(3):151-157. 

PNL -6583

UC-606

\section{DISTRIBUTION}

No. of

Copies

OFFSITE

10 DOE/Office of Scientific and Technical Information

DOE Headquarters

J. D. Foulke Office of Nuclear Safety

U.S. Department of Energy

Washington, DC 20545

G. W. Gibbs, Acting Assistant Secretary for Environment, Safety, and Health

U.S. Department of Energy Washington, DC 20545

J. P. Knight, Acting Director Office of Nuclear Safety

U.S. Department of Energy

Washington, DC 20545

5 Bette L. Murphy

Office of Nuclear Safety

U.S. Department of Energy

Washington, DC 20545

D. R. Nelson

Office of Nuclear Safety

U.S. Department of Energy

Washington, DC 20545

R. W. Starostecki, Deputy Assistant Secretary for Safety, Health, and Quality Assurance

U.S. Department of Energy

Washington, DC 20545
No. of

Copies

J. C. Tseng, Acting Director

Office of Environmental

Guidance and Compliance

U.S. Department of Energy

Washington, DC 20585

E. J. Vallario, Acting Director Radiological Controls Division U.S. Department of Energy Washington, DC 20545

DOE Albuquerque Operations Office

R. E. Alexander

Pantex Plant

Mason \& Hanger--Silas Mason Co., Inc.

P.0. Box 30020

Amarillo, TX 79177

W. D. Burnett

DOE Sandia National Laboratories

Mail Code 3312, Bldg. 8619

P.0. Box 2800

Albuquerque, NM 87115

G. W. Campbell

Rockwell International

Rocky Flats Plant

P.0. Box 464

Golden, CO 80401

J. W. Doty

Mound Laboratory

Monsanto Research Corporation

Miamisburg, $\mathrm{OH} 45342$

J. Haynie

Los Alamos National Laboratory P.0. Box 1663

Los Alamos, NM 87545 
E. L. Headrick Lovelace ITRI

P.0. Box 5890

Albuquerque, NM 87185

J. M. Langsted

Rockwell International

Rocky Flats Plant

P.0. Box 464

Golden, CO 80401

R. G. Stafford

Los Alamos National Laboratory

P.0. Box 1663

Los Alamos, NM 87545

J. G. Themel is

U.S. Department of Energy

Albuquerque Operations Office

P.0. Box 5400

Albuquerque, NM 87115

J. J. Thompson

Lovelace Biomedical \&

Environmental Research

Laboratories

Health Protection Operations

P.0. Box 5890

Albuquerque, NM 87115

M. Winegardner

Monsanto Research Corp.-Mound

P.0. Box 32

Miamisburg, OH 45342

DOE Chicago Operations Office

R. Allen

Radiation Physics Staff Group

Fermi National Accelerator Laboratory

P.0. Box 500

Batavia, IL 60510
L. V. Coulson

Fermi National Accelerator Laboratory

P.0. Box 500

Batavia, IL 60510

E. H. Dolecek

Argonne National Laboratory

9700 S. Cass Ave., B1dg. 201

Argonne, IL 60439

W. Freeman

Radiation Physics Staff Group

Fermi National Accelerator Laboratory

P.O. Box 500

Batavia, IL 60510

R. A. Mayes

U.S. Department of Energy

9800 S. Cass Ave.

Argonne, IL 60439

C. B. Meinhold

Brookhaven National Laboratory

Associated Universities, Inc. Upton, NY 11973

D. P. O'Neil

Argonne National Laboratory

9800 S. Cass AVenue

Argonne, IL 60439

DOE: Idaho Operations Office

J. H. Barry

U.S. Department of Energy

Idaho Operations Office

785 DOE Place

Idaho Falls, ID 83402 
No. of

Copies

D. Carlson

U.S. Department of Energy

Idaho Operations Office

785 DOE Place

Idaho Falls, ID 83402

J. P. Cusimano

U.S. Department of Energy

Idaho Operations Office

785 DOE Place

Idaho Falls, ID 83402

T. F. Gesell

U.S. Department of Energy

Idaho Operations Office

785 DOE Place

Idaho Falls, ID 83402

F. Jakubowski

EG\&G Idaho

P.0. Box 1625

Idaho Falls, ID 83401

R. U. McMannon

EG\&G Idaho

P.0. Box 1625

Idaho Falls, ID 83401

B. L. Rich

EG\&G Idaho

P.0. Box 1625

Idaho Falls, ID 83401

A. N. Tschaeche

WINCO

$\mathrm{M} / \mathrm{S}$ CPP -630

P.0. Box 4000

Idaho Falls, ID 83403
No. of

Copies

DOE Nevada Operations Office

A. E. Bicker

Reynolds Electrical \&

Engineering $\mathrm{Co}$. , Inc.

P.0. Box 14400

Las Vegas, NV 89114

P. K. Fitzsimmons

U.S. Department of Energy

Nevada Operations Office

P.0. Box 14100

Las Vegas, NV 89114

R. M. McAdams

Mason \& Hunger-Silas Mason

Co., Inc.

Pantex Plant

P.0. Box 30020

Amarillo, TX 79177

J. E. O'Brien

USAF

OEHL/RZE

Brooks AFB, TX 78235

D. Thorne

U.S. Environmental Protection Agency

P. 0. Box 15027

Las Vegas, NV 89114

I. J. Wells

Reynolds Electrical \& Engineering Co.

P.0. Box 14400

Las Vegas, NM 89114 
No. of

Copies

DOE Oak Ridge Operations

Office

J. C. Bailey

Oak Ridge Gaseous Diffusion Plant

P.0. Box $P$

Oak Ridge, TN 37830

J. S. Bogard

P.0. Box $Y$

Oak Ridge, TN 37830

R. J. Cloutier

Oak Ridge Associated Universities

P.0. Box 117

Oak Ridge, TN 37831

K. Edwards

Paducah Gaseous Diffusion Plant

P.0. Box 1410

Paducah, KY 42001

R. E. Halliburton

Oak Ridge National Laboratory

P.0. Box $X$

Oak Ridge, TN 38730

S. L. Hinnefeld

Westinghouse Materials Co. of Ohio

P.0. Box 398704

Cincinnati, $\mathrm{OH} 45239$

D. B. Howard

U.S. Department of Energy Oak Ridge Operations Office P.0. Box E

Oak Ridge, TN 37831
No. of

Copies

J. M. Mahathy

Martin Marietta Energy Systems, Inc.

P.0. Box P

Oak Ridge, TN 37831

W. T. Mee

$Y-12$

P.O. Box $Y$

Oak Ridge, TN 37830

D. C. Parzyck

Oak Ridge National Laboratory

P.O. Box $X$

Oak: Ridge, TN 37830

S. F. Seltzer

Paducah Gaseous Diffusion Plant

P.O. Box 1410

Paducah, KY 42001

J. E. Shoemaker

Oak Ridge Gaseous Diffusion Plant

P. 0. Box $P$

Oak Ridge, TN 37831

F. G. VanLoocke

RMI Company

P.0. Box 579

Ashtabula, OH 44004

E. R. Wagner

Portsmouth Gaseous Diffusion Plant

Martin Marietta Energy Systems

P.0. Box 628

Piketon, $\mathrm{OH} 45661$ 
No. of

Copies

DOE San Francisco Operations Office

T. R. Crites

Lawrence Livermore National Laboratory

P.0. Box 5505

Livermore, CA 94550

J. T. Davis

U.S. Department of Energy

San Francisco Operations Office

1333 Broadway

Oakland, CA 94612

C. Graham

Lawrence Livermore National Laboratory

P.0. Box 5505

Livermore, CA 94550

T. Greenhouse

Lawrence Livermore National Laboratory

Berkeley, CA 94720

R. V. Griffith

Lawrence Livermore National Laboratory

P.0. Box 5505

Livermore, CA 94550

R. C. McCall

Stanford Linear Accelerator

P.0. Box 4349

Stanford, CA 94305

R. H. Thomas

DOE Lawrence Berkeley National Laboratory

University of California

Berkeley, CA 94720
No. of

Copies

G. Warren

Stanford Linear Accelerator

Center

P.0. Box 4349

Stanford, CA 94305

D. Wright

$\mathrm{M} / \mathrm{S} 8263$

Sandia National Laboratories

Livermore, CA 94550

DOE Savannah River Operations Office

D. N. Bridges

U.S. Department of Energy

Savannah River Operations Office

P.0. Box A

Aiken, SC 29801

K. Crase

E. I. duPont de Nemours \& Co.

Savannah River Plant

Aiken, SC 29809

A. R. Goodwin

E. I. duPont de Nemours \& Co.

Bldg. 735-A

Savannah River Plant

Aiken, SC 29809

W. C. Reinig

E. I. duPont de Nemours \& Co.

Savannah River Plant

Aiken, SC 29809

EPA Office of Radiation Programs

A. Richardson

401 M Street, SW

Washington, DC 20460 
No. of

Copies

National Center for Devices and Radiological Health

J. C. Villforth

FDA Bureau of Radiological Health

Rockville, MD 20852

National Bureau of Standards

E. H. Eisenhower

National Bureau of Standards

Gaithersburg, MD 20899

J. Pruitt

National Bureau of Standards

Gaithersburg, MD 20899

R. B. Schwartz

National Bureau of Standards

Gaithersburg, MD 20899

Nuclear Regulatory Commission

R. E. Alexander

U.S. Nuclear Regulatory Commission

Washington, DC 20555

Other

R. A. Burkhart

General Electric Company

P.0. Box 11508

St. Peterburg, FL 33733
No. of

Copies

M. C. Collins

The Bendix Corporation

P.0. Box 1159

Dept. 442, Stop ME49

Kansas City, MO 64141

T. A. Dugan

NLO, Inc.

P.0. Box 39158

Cincinnati, $\mathrm{OH} \quad 45339$

J. R. Fennimore

Princeton Plasma Physics Lab

P.0. Box 451

Princeton, NJ 08544

A. J. Tarab

Garratt AiResearch

252.5 W. 190th Street

Torrance, CA 90504

3 DOE Richland Operations Office

D. T. Evans

D. L. Hoff

D. L. Sours

2 Westinghouse Hanford Company

L. K. Aldrich II

R. 0. Budd 
No. of

Copies

90 Pacific Northwest Laboratory

W. J. Bair

L. W. Brackenbush

F. M. Cummings (15)

G. W. R. Endres

L. G. Faust (10)

D. R. Fisher

J. J. Fix

G. R. Hoenes

C. D. Hooker

J. R. Johnson

J. L. Kenoyer

J. A. Leonowich
No. of

Copies

J. B. Martin

J. C. McDonald (10)

L. A. Rathbun

J. M. Selby (30)

K. L. Soldat

J. G. Stephan

C. M. Stroud

K. L. Swinth

M. T. Upton

Health Physics Department Library

Publishing Coordination (2)

Technical Report Files (5) 


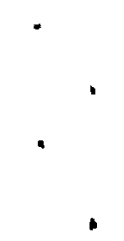

